ZYLBERMAN, Patrick. "Debordering" public health: the changing patterns of health border in modern Europe. História, Ciências, Saúde - Manguinhos, Rio de Janeiro, v.27, supl., set. 2020, p.29-48.

Abstract

"Debordering" public health: the changing patterns of health border in modern Europe

Tirando as fronteiras da saúde pública: mudanças nos padrões de fronteira sanitária na Europa moderna

Patrick Zylberman ${ }^{i}$

' Emeritus professor of the history of health, École des hautes études en santé publique/Université Sorbonne-Paris-Cité. Paris - France

orcid.org/0000-0001-8429-9713

patrick.zylberman@gmail.com

Received on 17 June 2019.

Approved on 11 Nov. 2019.

Translated from French by Mark Thompson.
According to David Fidler, the governance of infectious diseases evolved from the mid-nineteenth to the twentyfirst century as a series of institutional arrangements: the International Sanitary Regulations (non-interference and disease control at borders), the World Health Organization vertical programs (malaria and smallpox eradication campaigns), and a post-Westphalian regime standing beyond state-centrism and national interest. But can international public health be reduced to such a Westphalian image? We scrutinize three strategies that brought health borders into prominence: pre-empting weak states (eastern Mediterranean in the nineteenth century); preventing the spread of disease through nation-building (Macedonian public health system in the 1920s); and debordering the fight against epidemics (1920-1921 Russian-Polish war and the Warsaw 1922 Sanitary Conference).

Keywords: international public health; border; epidemics; history.

Resumo

Segundo David Fidler, a gestão de doenças infecciosas entre meados do século XIX e e o XXI guiou-se por uma série de acordos institucionais: Regulamento Sanitário Internacional (não interferência e controle de doenças em fronteiras), programas verticais da OMS (campanhas de erradicação da malária e varíola), e posicionamento pós-vestefaliano além do estado-centrismo e interesse nacional. Mas pode a saúde pública internacional ser reduzida à tal imagem vestefaliana? Examinamos três estratégias que destacaram as fronteiras sanitárias: prevenção em estados vulneráveis (Mediterrâneo oriental, século XIX); prevenção à disseminação de doenças via construção nacional (sistema público de saúde macedônico, anos 1920); remoção de fronteiras no combate às epidemias (guerra polaco-soviética, 1920-1921 e Conferência Sanitária de Varsóvia, 1922).

Palavras-chave: saúde pública internacional; fronteira; epidemia; história. 
$\mathrm{T}_{\mathrm{a}}^{\mathrm{h}}$ he fate of populations and states plays out at borders: "Any great power that fails adequately to protect its frontier ceases to be great, any great Empire that neglects this important duty of self-preservation is eventually overthrown" (Collin Davies, 1975, p.2). The same applies to the fate of public health, something that surely did not escape the attention of western and Asian countries when facing the SARS (Severe Acute Respiratory Syndrome) outbreak in 2003, or during reports of avian flu two years later. Today, some people proclaim the demise of the health border, yet states were quick to seal their borders when faced with BSE (bovine spongiform encephalopathy, or the "mad cow disease") and when foot-and-mouth disease struck western Europe in the spring of 2001. Despite being a universal system, international public health draws on the expertise and politico-scientific ethics of the West (Merton, 1942), and as such it mimics the position of US hegemony - a post-territorial empire that is nevertheless required to protect all its borders and territories of strategic interest from potential threats (Maier, 2006, p.282). Border controls and surveillance technology may change but the strategic value of the boundaries of political space remains, with terrorism and bioterrorism serving as a reminder of the absolute need to keep watch over the "limes" (p.110).

Letting go of the "Westphalian" public health system turned out to be just a bureaucratic token, a mirage, a variation on the theme of the end of history. The events of 9/11 would change this ideological representation of the western world, which had prevailed since the fall of the Berlin Wall in 1989.

\section{The problem}

In the same way as empires, public health leans inwards from the outside. The center and periphery together determine policy developments in public health. The latter changes internal society through a set of rules that relate to the control of the outer fringes of said society. For instance, even overseas empires, such as those of Britain and France, had to keep a watchful eye on their borders and territories despite being focused on controlling routes and trade, as rival empires could be a threat. Stabilization of borders is key to the security and prestige of the center, writes Charles Maier (2006, p.79, 82); in other words: the way in which international public health is organized is a key component for states in their health policy-making. For at least a century (1850-1950), public health in Europe was imperial public health. However, "imperial" does not necessarily mean imperialistic. In the Mediterranean, although colonial policy was a constituent part of British, French, Dutch, and Turkish health policy, rivalry in health between East and West cannot really be regarded as colonial policy. Rather, it was rivalry in imperial policy (with Constantinople, like other western capitals, favoring remote government), as well as rivalry between European powers. Imperial here is more about the various powers seeking to (better) protect themselves from germs by establishing their sanitary frontiers as far out as possible. In the wake of the First World War, the emerging nationalisms would disrupt this pattern to some extent, but without radically changing it.

The typology presented here refers less to the physical features of the health border "topology not destiny" (Baldwin, 1999, p.553) - than to its strategic functions. With regard to 
epidemics and public health, we postulate three policy approaches: preemption, prevention, and functional debordering. Each approach is historically linked to a pathological category but the word "historically" should not be taken to mean determinism. It is, however, insightful to notice that the preemption border is associated with cholera, while the prevention border is associated with malaria; preemption led to public health councils, while prevention led to dispensaries. In the words of Charles Maier (2006, p.155), "institution-building in imperial structures actively involves the bordering process." (This remark applies, of course, to all types of state, of an imperial or national configuration.) After reviewing each approach to the health border, we will look at how this paradigm may have shifted when borders "reappeared" between 1996 and 2001 during the BSE and foot-and-mouth disease epidemics. Lastly, just as for Maier the history of empires reflects that of their frontiers, so for us the history of public health reflects that of its geopolitical boundaries. ${ }^{1}$ Before we examine the three policy approaches to the health border, we should look at a classic example of a health border which widely inspired the nineteenth and twentieth centuries.

\section{A template: the Austrian Pestcordon, 1710-1873}

The military frontier, or Militärgrenze, between Austria and the Ottoman Empire stretched 1,900km from the Adriatic to the Carpathians. By the late eighteenth century, some 824,000 colonists inhabited the borderland (Lesky, 1957, p.84, 89; Rothenberg, 1973, p.17; Tomasevich, 1955, p.74-81), ${ }^{2}$ making it a "living rampart." Farmer-soldiers manned this buffer zone against possible Turkish invasion and were tasked with preventing plague and cholera from crossing into Austrian territory from the East. Signed in 1718, the Peace of Passarowitz (Pozarevac) governed Austro-Turkish relations along the Danube. The Ottoman empire had effectively lost ground in Europe by this time. Following this, two closely coordinated objectives came to the fore: militarization and medicalization of the frontier. The Habsburgs decreed a strange measure: in order to facilitate trade with the Balkans, an impassable barrier should be erected.

At the beginning, the military frontier was a purely defensive line, without any forward control at the frontline (Rothenberg, 1979, p.375-377; Braudel, 1966, p.174-176). Although epidemic surveillance measures had been planned from the late seventeenth century, no quarantine facilities were set up prior to 1710 (Nouzille, 1991, p.113). At this time, a decision was taken to check health passports, with post riders notifying Vienna of any cases of infection. This system remained provisional until 1728, after which time, in various stages, the frontier became a thorough health screen.

Actual medicalization of the frontier only began some ten years later with the arrival of Austrian medical personnel, who issued bimonthly reports for Vienna. At the same time, local health commissions reporting to the capital were set up in the borderland, for example at Hermannstadt (Sibiu) in 1737, and then in each "regiment" (sector). From 1740, the central authorities issued health regulations for the frontier and opened a number of quarantine stations, Rastelle (halts) at secondary crossing points, and Kontumazen (lazarettos) at checkpoints for travelers and goods. The former were basic enclosures watched over by guards, through which merchandise, money, and mail could pass. The latter featured a 
guardhouse and lazaretto and were placed under the orders of a lieutenant supported by thirty cavalrymen, and managed by a surgeon.

The quarantine stations were surrounded by three-foot-high walls. Palisades separated the exposed compartment from the unexposed compartment and a guard was on duty to maintain order. Each compartment contained its own store, stables, cowshed, and courtyard. The exposed compartment also had accommodation.

Station staffing levels were quite high in some places, reaching 54 people at Semlin (opposite Belgrade) in 1823, for example. Promulgated by Maria Theresa in 1770, this quarantine set-up would only be enshrined in law in 1837. A chain of outposts would thus be established within musket range, virtually closing off the border with Turkey (Lesky, 1957, p.94; Rothenberg, 1973, p.18-19). Under normal circumstances, some four thousand men were on duty, but this figure could reach seven thousand if an epidemic was declared in Constantinople, and eleven thousand if disease broke out in Moldavia, Vallachia, Serbia, or Bosnia. Enforcement was strict and anyone infringing the health regulations could be shot - all while the queen was abolishing torture in the Empire (Lesky, 1957, p.89). Public services and the status of individuals were all overhauled under Maria Theresa, thus completing a system that her father, Charles VI, had elaborated at the beginning of the century. And the Militärgrenze became at this time the largest and most comprehensive health undertaking in Europe.

In 1776, as if to sublimate the undertaking, the health border was placed under the authority of the Hofkriegsrat, the Imperial War Council in Vienna. Subsequently, all the borderlands along with administration of the cordon sanitaire and quarantines turned into a sort of corpus separatum, or "autonomous military state" (Rothenberg, 1979, p.365; Nouzille, 1991, p.254).

Until the turn of the eighteenth century, the military frontier apparatus was sparsely populated and quite basic. However, the queen introduced freedom of worship (albeit reluctantly), which encouraged a considerable number of colonists to settle in the zone. They were a mix of Catholic Croats and Orthodox Serbs who had fled Turkish-occupied Serbia, but also Romanians, Hungarians, Germans, Albanians, and others. It was a "great experiment of colonizing a region partially uninhabited and partially reconquered" from the Osmanlis (Rothenberg, 1979, p.361, 381). While this defensive strip remained military and political in nature, it progressively turned into a place of settlement and subsistence farming, taking on an economic and "national" character. This was officially enshrined in 1871, when the civil authorities took back control. A whole region of central and south-eastern Europe would draw its roots and some of its future identity from this. However, this colonization did not lead to increased farmland or food production as it remained a military endeavor in nature. Joseph II (Maria Theresa's son, collaborator, and successor) introduced reforms to replace the defensive frontier with a policy to reorganize the borderlands. This included protection against plague, modernization of farming, rural planning, urban development, and planned immigration (Thomas, 1984, p.8-13). Despite all this, the borderlands remained in a state of extreme poverty.

To facilitate trade, there had been no quarantine restrictions under normal circumstances since 1785. In 1837, the quarantine period during epidemics was reduced from 42 to 21 days 
and the same regulation provided for showers at quarantine stations. Medicalization had been completed by 1807 and prevailed over any other function at the frontier. However, this did not mean medicine suddenly became the be-all and end-all of imperial expansion. As it improved the technical ability to control the frontier, this medicalization did undoubtedly bring the authority exercised at the cordon closer to the authority widely asserted by the Ministry of War. But this medicalized quarantine was all brought about through the militarization centralization and colonization - of the borderlands. And this led to a more modern state.

The Austrian cordon was much replicated. In 1830, the Russians established quarantine stations on the Danube in Moldova and Wallachia, areas which had recently been taken from the Sultan under the Treaty of Adrianople (1829). Based on the Austrian Rastelle and Kontumazen model, quarantine stations were set up along two lines of differing importance, where quarantine periods ranged from eight to 40 days. The Russian outposts characteristically materialized the military frontier as well as the health and customs border. In the Principality of Serbia too, the militia manned the cordon sanitaire similarly to the Austrian Grenzer (Panzac, 1986, p.96-98). Thus, with its Militärgrenze, Austria offered an invariable benchmark for health borders. This was the case even up to 1940s Indo-China, where an archetypal system of outposts (although run by civilian authorities) featured along the 1,800-kilometer-long frontier separating the French colony from China and Siam (Meyer, 1944, p.23-26). This cordon sanitaire was used to check the mass of refugees fleeing cholera in Yunnan (1937 and 1940) and smallpox (1938). From the time when Sultan Mahmûd founded the Health Council of Constantinople in 1838, forward epidemic control measures constantly increased. Of the thirty Council members, 23 were foreign doctors. From that year, the Ottoman Empire called on Austrians to organize quarantine and train students of the Mekteb-i Tibbiye-i Sahane military school of medicine, which had opened in 1827. Extending from the Black Sea to Nis, the Turkish cordon would enlist the support of Austrian, Italian, or German doctors. It was only in 1923 in Lausanne that this European quarantine in Turkey, part and parcel of the Capitulations, would be abolished and relinquished to Ankara (Unver, 1973, p.91-97).

The health border was more than its name suggests; it was also a racial border, a border between civilizations, and a border of modernization. It may have been a rampart against Ottoman invasion, but the frontier was many things besides. It was about planned immigration, rural planning, efforts to integrate peasants of diverse ethnic backgrounds. The backdrop was a policy to reorganize and reconstruct the borderland towns and villages and to introduce freedom of worship and tax incentives for new settlers. These features will appear in our typology. The idea of modernization undoubtedly overlooked backward features such as persistent serfdom in the borderlands (until 1848) or the expansion of latifundia following the Austro-Hungarian Compromise of 1867 (Thomas, 1984, p.9, 11). As such, development of the frontier remained highly dependent on its strategic function. "Power, not welfare" (Taylor, 1990, p.246-247) was key: the expertise upon which health systems and techniques relied (medicine, town planning) should not overshadow the rural and reactionary social order underlying the military borderland. ${ }^{3}$

Now, what is the justification for addressing the Austrian Pestcordon so extensively in this paper? What can we learn from this example? We think that vital tracks can be explored. 
One of these examines a recurring theme: the fact that politics that might appear highly technical at first glance may be politically dependent upon many departments of the government, the ministry of health, ministry of finance, or even the prime minister. This was one of the premises of the idea of global health that Gro Harlem Brundtland put forth in the 1990s (Cueto, Brown, Fee, 2019, p.285-286), and to which doctor Tedros Adhanom Ghebreyesus, director-general of the WHO, returned in 2017 (Reid, 2017). Other things being equal, such a health system at a border closely dependent upon the state is plainly visible when we look at the Austrian Pestcordon. Considering the Pestcordon as an example of a sanitary border zone is therefore not quite good enough for us. We may perhaps go so far as to add that it figures prominently as a pattern of the sanitary border in modern Europe from the end of the seventeenth to the middle of the twentieth century. Far from being only a cluster of characteristic features, the sanitary border is a combination of structural variables whose product should be analyzed. "Contingent sovereignty," a concept that is very briefly approached in this paper, is one instance of such combinations. Another one might be the "protection of the biological self," which is developed when the paper comes to Macedonia.

As a pattern, the Pestcordon allows us to identify the trends at work in the changes of the sanitary border. The three-step strategy we define in this paper are variations upon this pattern.

\section{An edge and a gangway}

Is global health transcending borders? Frequently, global health is described nowadays not only as a transdisciplinary body of knowledge and expertise, but more importantly as a form of public health that deals with issues transcending national boundaries (Fried et al., 2010; Koplan et al., 2009).

The liberal conception of the globalized economy is obviously not unrelated to this vision of global health. It presides over the thought of Jeffrey Sachs, the Harvard professor who in 2000 was appointed by Brundtland to head the WHO Commission on Macroeconomics and Health and was the subject of severe criticism, particularly by humanitarian organizations (Cueto, Brown, Fee, 2019, p.291-292). For in describing global health using the globalized economy as a template, we are faced with two contradictory observations: it can be said that a globalized economy may ignore national borders, while international policy emphasizes the importance of frontiers (Kissinger, 2014, p.368). ${ }^{4}$ And one cannot put aside the political order of the world. To define a frontier as a political entity is to regard it as an asymmetric membrane that is supposed to let people out "and" to prevent risks from crossing in. A frontier, sanitary or otherwise, is both an edge "and" a gangway. The politics surrounding frontiers are ambiguous.

The northern Vietnamese frontier, a sort of Pestcordon made in Asia at the time of the SARS outbreak (2003), offers a case in point. With the Chinese bending the rules and misleading the World Health Organization, SARS was in fact "a political challenge" (Rothstein et al., 2003, p.107-116). All along the border with China, the Vietnamese authorities built up a special organization. Everyday traffic was estimated at 5,000 persons. 
In order to detect, prevent, and treat infected people, Hanoi created six mobile teams (of ambulances and drugs) comprising physicians, nurses, caregivers, and drivers. Under the authority of an interdepartmental commission called Force Quarantenaire, the border with China became a key area in maintaining high-level day-to-day sanitary security in the northern provinces or in Haiphong Harbor. Prevention councils chaired by the provincial authority and staffed by border guards, police personnel, and immigration officials were posted at the border, as well as quarantine services working closely with the Ministry of Health.

Such a militarization of the frontier was a dangerous venture. And, indeed, it was not long before trouble arose. At the end of April, the Quang Ninh Province (north of the country) sent back every Chinese visitor except business people (after medical inspection), and forced 2,000 Vietnamese students who had been sent back by the Chinese authorities to go into collective quarantine. Strangely, this was just as China changed its tune after much agitation and Beijing started playing by the rules.

As only seven cases out of the 63 reported during the epidemic came from the northern provinces (the vast majority were detected in Hanoi), one can legitimately ask what the point was in imposing such a brutal cordon sanitaire. But the Vietnamese government's action was predicated on two key areas: public health and security. Far from "transcending" frontiers, global health is bound to operate in at-risk zones. Sanitary borders delineate hazardous areas or vulnerable zones. And this mixture of cross-border risk plus political frontier cannot but lead public health security to "a menacing geopolitical combination" (Bzrezinski, 2012, p.115-116). The history of sanitary borders combines these two components, an epidemiological component (border diseases or, in nineteenth-century parlance, "quarantine diseases") and a political component. Bringing together public health and national or collective security, geopolitics thus found its way into epidemic management. Such a trend is not at all on the way towards subsiding. On the contrary, it is becoming more complex: "As official concerns about migration, security and disease have increased, border controls have moved to the center of political debate" (Coker, Ingram, 2006, p.173). Here are some of the reasons why security questions could not be abandoned. ${ }^{5}$ We shall touch on the same issue in this paper when we develop the implementation of the "classical" system of maritime quarantine in the Red Sea. The central, crucial role of (national) security is part of the root of the history of the sanitary border.

\section{Health frontier: the classical system, 1897-2005}

According to David Fidler (2005), defense against infectious diseases evolved from the mid-nineteenth century to the beginning of the twenty-first century as a series of institutional arrangements. Although the International Sanitary Conferences were launched in 1850, the first Convention ratified by the High Contracting Parties was the 1897 Dresden Convention, and the 1903 Paris Convention was the first to be implemented. International public health policy was set out to offer "maximum protection" (from infection) with "minimum restriction" (on commerce) (Gostin, 2004). The State was supposed to be sovereign in its public health policy. Based on non-interference and disease control at the 
border, international public health law was thus "Westphalian" in character (Fidler, 2004) - except when it came to eastern countries.

What was the goal of the classical system? It was mainly to oversee health security issues originating in neighboring lands. A two-state dyad was thus devised to monitor natural and medical resources on both sides of the border. In the Mediterranean, both Britain and France established efficient systems in order to fulfill this task. When they established the Conseil Supérieur de la Quarantaine in Constantinople in 1838, and later a second Council in Alexandria in 1843, they began to monitor the Red Sea from Jedda thanks to a couple of diplomatic posts, one British and one French. In addition to protecting British and French interests, consuls started "keeping watch over the health status of a file 200,000 Mecca pilgrims more or less" (MAE, 27 Mar. 1867). Such a watch was in fact the most important part of their remit, along with monitoring Muslim Brotherhood activities in North Africa. In 1866, the French consulate in Jedda was "converted into an observation post almost entirely devoted to observing health in the region" (MAE, 3 Aug. 1867). Doctors took on both diplomatic and sanitary functions. Following a suggestion from the British ambassador to Constantinople, a vice-consul was sent to Jedda in 1882 who was both a physician and a diplomat, and also a Muslim. This enabled him to keep a close eye on health (plague and cholera) while watching over security (Roff, 1982, p.145, 148, 156). Ambiguity was the archetype of the sanitary border, as shown earlier by the Austrian Pestcordon. A sanitary border is a bridge, a gateway, and a meeting point; and at the same time a barrier, an obstacle, and a point of separation (Diener, Hagen, 2012, p.2). The classical, Westphalian system on which international public health was based was built upon such ambiguity. And eastern lands had no way to avoid finding themselves on the wrong side of the divide.

According to Fidler (2005), the fall of the classical system in 2005 in the wake of the SARS epidemic put the sanitary border system beyond state-centrism and national interest. Granted, many characters of the system had changed. The idea of pathologies that call for quarantine (plague, cholera, and yellow fever) has been replaced with the "public health emergency of international concern," which may be very different from any specific pathology. Only one provision of the International Sanitary Conventions remains in the reformed International Health Regulations, and that is that medical police still operate at borders, ports, and airports when there is an epidemic alert in place. Despite this, Fidler's "without-border" hypothesis is open to question. We would like to propose here an alternative narrative, namely, three different strategies that can be viewed as variations on the Habsburg Pestcordon configuration.

\section{Bordering health: a three-step historical stratification}

Three historical steps to the European sanitary border gave rise to three operational systems which integrated different combinations of public health, diplomacy, seaborne and land transportation, and frontier practice. Each system sought to satisfy a distinct set of priorities reflecting changing conceptions of international public health as well as the worldview and self-image of the partner states: imperial security (preemption), national security (prevention), or collective security (debordering). 
Preempting weak states (imperial security) was the dominant strategy in the eastern Mediterranean as of the 1866 Constantinople Sanitary Conference. It was based on the idea that the adoption by eastern Mediterranean governments of the "standard of civilization" (individualization of medical policing and legal normalization of health controls) would increase the state's strength, that is "the ability to formulate and carry out policies and ... to administrate efficiently" (Fukuyama, 2004, p.12).

The creation of the Health Section of the League of Nations in 1921 replaced this imperial policy with the prevention of the spread of disease through nation-building (national security). While preemption had implications for the ever-expanding hegemony of the great powers, prevention demanded an international cooperative framework (Lee, Buse, Fustukian, 2002). A strategic gap must therefore be added to the gaps in jurisdiction, participation, and incentives. Spurring national identities, prevention helped international public health move towards a national health order rather than towards a supranational health order.

When peace came in 1919, eastern Europe found itself submerged in devastating epidemics. To cope with these threats, the 1922 Warsaw Conference, organized by the Epidemic Commission of the League of Nations, proposed a "sanitary zone" straddling the Polish-Russian border after the 1920-1921 war. It tried to channel the flow of refugees, not within the traditional state-people-territory framework, but by temporarily and locally suspending national laws for the sake of a more functional approach. This approach did not, however, involve any attempt to lay down new lines of demarcation, but sought to deal with issues by "debordering" them. Let us turn now to each of the three health security approaches.

\section{Preemption: Mediterranean quarantine}

With preemption, security played a crucial part. In order to protect the Mediterranean from contamination through plague or cholera, the client states of the European powers, namely Turkey and Egypt, were to provide security beyond the frontier, in the Red Sea; something that Turkey failed to deliver. The powers were therefore preoccupied with obtaining from the Ottoman Empire a security set-up for sea crossings. The Turks were to operate the quarantine in Constantinople (1838) or Alexandria (1843). In fact the powers operated the quarantine all by themselves, while Turkey supported the operation financially. European powers thus projected their authority over the eastern Mediterranean, where they traded and clashed, without any translocation of any political entity other than the sanitary frontier under the guise of the médecins sanitaires d'Orient, a forward defense line established by the French (though Austria-Hungary had done so first) in Constantinople, Smyrna, Alexandria, Cairo, Beirut, and Damascus as of 1847. These medics acted as genuine "sanitary intelligence agents" for the consuls (Proust, 1896, p.34; 1897, p.347; Rey, 1874, p.134; Fauvel, 1882, p.6).

The Mediterranean could be as much a barrier as a highway, as it had been since the Romans (Luttwak, 1976, p.81). But of course, by the time steam-powered vessels came about, the Middle Sea had become much less of a barrier and more of a highway. The high 
ratio between the speed of seaborne transport and the small size of the bordered areas put the British and French at loggerheads over the containment of plague and cholera. The French wanted defense to be concentrated in the Red Sea - beyond the defense perimeter - in order, for example, to keep the 1865-1866 maritime cholera from reaching the Mediterranean Sea. Contrary to this high-intensity risk policy, Britain proposed a low-intensity risk one, namely a preclusive strategy (surveillance and alert), whereby a dispersed chain of lazarettos would supposedly enhance the reliability of surveillance while reducing the quantity of manpower and facilities needed to protect against the multi-directional spread of infection.

Against a backdrop of Westphalian dynamics, the preemptive sanitary border sought an uneasy balance between maximum security and maximum exchange, between concentration and dispersion of defense.

\section{Prevention: protecting the "biological self"}

A sanitary border can also act as a wall or a fence in a metaphorical way. Let us take the case of Yugoslav Macedonia in the 1920s and 1930s. It was a land whose borders were not exactly defined. This was common to many countries before the age of the nation-state, a time when "people went to and fro across the frontier without encumbrance" (Vidal de La Blache, 1994, p.80). The advent of the nation-state changed everything. Frontiers were now seen as gulfs dividing people morally. The Balkan Wars (1912-1913) had shown that Yugoslav Macedonia was claiming an imagined frontier that envious neighbors (Bulgaria, Albania, and Greece) did not recognize. But how to turn former soft limits into actual boundaries? Without validated demarcation, closing the border was the ultimate weapon (Foucher, 2012, p.7).

A sanitary border (against malaria) was the embodiment of this weapon. Instead of a frontier wall, fortresses, frontier settlements, or strategic towns, the Macedonian border became real through fountains, wells, dispensaries, and small bacteriological laboratories along the delineation of the political boundary facing the three other countries. The health cordon was loosely connected with malaria prevalence. And so practices of health bordering gave rise to hardened borders. The Yugoslav Macedonian sanitary border defended the biological identity of the people by creating (invented) "natural" frontiers in a place where the ethnic fabric was rather complex on both sides of the fence.

In Macedonia, the factors behind the spread of malaria around 1920 and 1930 included anthropogenic determinants such as new agricultural practices (rice-growing), a new way of life (the Turks had been expelled), migration (settlers), and lack of sanitation. Following the failure of the first wave of Serbian colonization at the end of the war (1919-1922) (Kitron, 1987, p.315; Ancel, 1930, p.87; Hollmann, 1928, p.288; Ottolenghi, 1924, p.25-26), Belgrade decided to carry out major works (draining swamps, destroying larval breeding grounds) and reorganize the distribution of quinine (mainly for the armed forces), as well as providing health education, especially in rural areas.

These technical aspects should not overshadow the politics behind this state undertaking. The new Yugoslav State aspired to the nineteenth-century concept of the 
nation-state, where state boundaries should coincide with cultural boundaries. However, these are always shifting and contentious, particularly in an extricably complicated region made up of diverse ethnic groups.

Public health had its part to play in this "rebordering" process, the opposite of the "debordering" that took place following the war and its forced population displacements. A long cordon ran along the Macedonian border with Bulgaria, Greece, and Albania formed of dispensaries and sanitary stations to counter the spread of malaria. It effectively materialized a demarcation line that had been blurred by war and migration. The levels of mortality due to malaria differed between the Yugoslav, Greek, and Bulgarian parts of Macedonia. The disease also regressed at different rates for Serb and Muslim villages. This all contributed to making the boundaries more "natural," despite the ethnic patchwork in the whole region. Therefore the sanitary facilities and epidemiological data (interpreted misleadingly) marked out a "biological self" (Moulin, 1991, p.244-257) underpinning individual and collective identities, just like the borders of a nation-state. It is hardly surprising that the defensive curtain set up by the province of Belgrade against disease from 1923 would fit snuggly onto the geopolitical lines of force previously established by the geographer Jovan Cvijic: the Drin, the Vardar, and the Macedonian borderland next to Bulgaria. Was it any surprise that these were the lines of force of the Serbian dream to internally colonize Macedonia (Cvijic, 1918, Annex) ${ }^{6}$

What we have here is nothing but one additional instance of a health frontier turning out to be some kind of menacing geopolitical combination, as discussed at the start of this paper. The polarization of the fight against malaria did indeed play a crucial role in "inventing" identities within the Balkans. By medicalizing the newly conquered lands, the Serbs found a way to defend Macedonia against any foreign desires, and make it a "genuinely" Yugoslav province. Going back to what Owen Lattimore, the great American geographer, said, borders are not only for "keeping out" but also for "keeping in" (Lattimore, 1962a, p.98, 112). And as the director general of Health in Belgrade Andrija Stampar (1966, p.62) said: "a nation's social revival is at the same time a nation's sanitary revival."

\section{Debordering practices: the "sanitary zone" (1922)}

The territorial obsessions of the Peace Conference undermined efforts to curb epidemics, something that the continent's revival heavily relied upon. In eastern and south-eastern Europe, peace came about in the midst of an onslaught of epidemics that nothing seemed able to halt. Just as freshly redrawn maps of the "dark continent's" national and ethnic structures were emerging from the chaos of war, outbreaks of dysentery, malaria, tuberculosis, cholera, and typhus struck. In European Russia alone, there were thirty million cases of typhus and three million deaths between 1917 and 1923 (Zinsser, 2000, p.213, 133; Mazower, 1998). For Ludwik Rajchman (1922a), medical director of the League of Nations Epidemics Commission, the return of civilization and progress depended on ensuring sanitary security and the eradication of the "black death" in the East. So many things - such as setting up an administration, defining borders, and facing the threat of bolshevism - hinged on fighting contagious disease and malnutrition. As states and borders 
were just being reshaped and demarcated, the issue of a sanitary border came to the fore. The timing was tragic.

The "common" threat did not inspire a "community" of vigilance or a "community" spirit, despite a feeling of reciprocal vulnerability. What organizing power could deal with this common issue? The war-weary, who flowed into each other's territories from neighboring zones to form a single wretched mass, found diverse entities attempting to deal with them: international organizations (e.g., League of Nations Health Committee), charitable or philanthropic organizations (Nansen, Rockefeller Foundation, Save the Children etc.), and military medical missions dispatched by the powers in eastern Europe. Hardly had the principle of nationalities been proclaimed than it was undermined from above by the rise of humanitarian and international organizations and from below by the hordes of refugees and displaced persons. A framework and mechanism for interstate health cooperation were needed and the urgency of the context alone would not bring this about. For Wickliffe Rose, head of the Rockefeller Foundation International Board, only a large-scale counter-offensive free of the shackles of state boundaries and organized by an international technical authority could rid this new Europe of its woes (Rose, 1920; Rajchman, 1922a).

On March 20 and 28, 1922, a European Health Conference was held in Warsaw to tackle typhus and cholera in Poland and Russia (Société des Nations, 3 Apr. 1922). The aim was to design the tools for this global counter-offensive, specifically a "sanitary frontier zone" to control and monitor refugees in areas both sides of the border, which was implemented in 1921-1923. The zone occupied a strip 150km wide on each side of the Polish-Russian border. It came under mixed jurisdiction, with international oversight, while the legal validity of the border was kept intact. Alongside the cycle of demarcating the borders of where a state began and ended, a cycle of sanitary frontier-building also took place that saw the setting up of public services (cordons, disinfection stations, surveillance, and observation), on the one hand, and special status granted to individuals (cross-border workers, migrants, travelers, pilgrims, refugees) across frontiers, on the other hand. Here, practicalities in the field clearly impinged on the political idea of statehood, but international oversight did not mean any laying down of new lines of demarcation (Albert, Brock, 1996, p.70). Of Italian and German origin (Rajchman, 1922a, 1922b), the idea of a health border zone was based on the traditional definition of three spaces put forward by Ratzel in Politische Geographie (1897). He stated that a border was more than a simple line; it juxtaposed two opposite zones, each under the control of a different nation-state, and an in-between zone of fusion that came out of the "development of the border within the border area" (Geouffre de Lapradelle, 1928, p.226). The region that Owen Lattimore (1962b, p.15-16) more appropriately called the "zone of differentiation" is a marginal interstice that is regularly a matter of dispute and is not under the permanent control of any bordering state. In this control and surveillance zone set up by the Epidemics Commission in Poland, we find this ambivalence of the border mentioned earlier (Lattimore, 1962b, p.470).

The sanitary border surely tried to channel the flow of people, but not within the "statepeople-territory" framework used for sovereignty (national defense). Instead, the sanitary border is a "borderless" procedure that organizes a local space, not a demarcated one. This does not, of course, mean the demarcated space (national defense) disappears; rather, it is 
suspended temporarily or functionally, as was the case in the 1950s and 1960s during the WHO's "vertical" campaigns. The sanitary border therefore has a close connection with complex emergency situations. As an ideology and approach to international relations, functionalism attempts to substitute world affairs with foreign affairs. This would put international affairs under a world council for world affairs (Madariaga, 1937, p.105).

Lastly, this sanitary border zone offers a mix of sanitary border models in the twentieth century. The defense zone materialized the cordon sanitaire against infectious disease and bolshevik contagion, which would stretch from the Baltic to the Black Sea. The sanitary zone formed a medical no-man's land where states and people could exist next to each other without interacting. This sanitary border also offered a politically correct way and the technical means of shoring up a "biologically just border," as put forward by the German Geopolitiker; it was more of a zone for managing flows, pilgrims, immigrants settlers, and refugees than an actual line (Ancel, 1938, p.185). ${ }^{7}$

Set within physical, anthropological, and geographical borders that were relatively ill-defined, these new and still unstable states created from the peace of 1919 dreamed of compensating for this predicament with a determinism that would encourage and impose such demarcations as land- or sea-based quarantine, albeit discreetly. Something that these peoples had always fanatically cherished (Protocoles..., 1885, p.56, 348; Proust, 1897, p.306-324; Goodman, 1971, p.58).

Incidentally, this was not really anything new, as powerful countries had already done the same thing: from the 1890s, Germany had set up a series of dispensaries and delousing stations against typhus on its eastern border, and America had medicalized and militarized its southern border (Rio Grande) and eastern border (Ellis Island).

To evolve from the Pestcordon to a sanitary frontier zone, the European sanitary "limes" underwent profound change. The wall, claimed to be insurmountable, turned into an illusory sentry walk. Then came the zone of differentiation. The idea had first been to stop infiltrations and then to monitor flows. The codification of such sanitary zones by the conferences of Dresden in 1887, Paris in 1903, and then Warsaw in 1922 was part of an effort to keep epidemics from spreading via major population movements (e.g., cholera from Mecca, typhus from Warsaw).

It would, however, be a mistake to consider the sanitary frontier zone as just a modern version of the Pestcordon. When a sanitary zone is set up, the borderline fades into the background, giving way to a series of disinfection stations and logistics to control population flows. Such a system gives ample opportunity to oversee flows of refugees and monitor their health status. It is no longer built upon the traditional state-people-territory framework; it is more flexible and fluid, and championed by numerous actors who make the case that protecting the health of refugees requires international action. It allows bordered countries to claim a contingent sovereignty (Diener, Hagen, 2012, p.68; Marrus, 1985, p.82-86). In lieu of a linear, multi-purpose frontier, the sanitary border is now made of screening points that multiply within a networked space. This "networked frontier" 8 temporarily and locally suspends national laws for the sake of a more functional approach that transcends the territory, but without any attempt to lay down new lines of demarcation. It attempts to handle problems by "debordering" them. 
Assuredly, the sanitary zone represents an innovative concept for a health border as it provides a broader definition of border space. A world of flows is replacing a world of places. But what does this mean? Is there any chance that these changes may lead to a permanently borderless landscape some day?

\section{A "neofeudal" health frontier}

Today, some people entertain the idea of a borderless world. And indeed, the proliferation of sub-state or non-state actors brings the Westphalian model of sovereignty into question. Such a process could lead to the emergence of "neofeudal" networks with conflictual situations, pitting people with privileges and people suffering discrimination against each other (Diener, Hagen, 2012, p.123). The privatization of quarantine surrounding a district in Sierra Leone in the spring of 2014 is a case in point.

As in neighboring Liberia, Ebola led to the collapse of state services in Sierra Leone. Overrun with sickness and violence, the health system, police, and army were all laid in tatters. Momoh Konte, a Sierra-Leone businessman born in the Koinadugu district, a poor, mountainous district bordering Guinea and home to 265,000 inhabitants, gave SLL 10 million (USD 1,100) for the fight against Ebola. Koinadugu was surrounded by districts dealing with hundreds of cases. Village leaders and local politicians sided with Konte. In spring 2014, the Koinadugu district was the last Ebola-free district in Sierra Leone. Residents could not go out, and visitors had to be "invited" by residents. The amount of SLL 45,000 (renewable) was given to import necessary goods, whose delivery was coordinated through a task force. Village leaders had to organize guards to implement fresh rules and educate people in health prevention. Traditional healers were mobilized and compensated. In spite of this, in September that year, a man infected with Ebola was smuggled into the district. Young people alerted district health officials. The man and his wife were escorted out of the district, the house where they stayed was disinfected, and contacts were quarantined (Frankel, 10 Oct. 2014).

There is a postscript to this story. In late October, two cases were discovered. Then, a dozen more. At the beginning of November, the number of new cases rose to sixty. The United Nations labeled Koinadugu an Ebola hotspot. Under the authority of the rich businessman, quarantine became thicker and darker. "Secret agents" were hired in order to report signs of secret burials and people hiding Ebola patients. Four homes where Ebola sufferers lived were burned to the ground by the local Ebola task force (Frankel , 12 Nov. 2014).

The neofeudal (neoliberal) frontier takes advantage of a borderless world, but only as an emergency endeavor. Once the epidemic abates, the barrier is dismantled. We are sent back to the old systems of quarantine, when, except for major cities, which had permanent Magistracies of public health, towns and rural communities built health boards only in times of emergency (Cipolla, 1981, p.4). The prospect of a permanently borderless health world remains highly unlikely. In fact, the boot is on the other foot nowadays. Recent pandemics and epidemics have not substantiated the post-Westphalian idea. As the recent BSE crisis clearly showed, the focus on microbial threats has led to the rekindling of borders during emergencies. And preemptive interventions in defective states have become a key 
element in international health politics, such as in the SARS outbreak of 2003. The rise and fall of the Westphalian system are only segments of the full story.

This paper has tried to make the case for the "preemption/prevention/debordering" hypothesis as a more comprehensive picture of the politics of international public health in the twentieth century. Our problem still has to be put into the broader context of the border crises in Europe in the 1870s and 1950s. In September 1896, in his speech in Varzin (East Prussia), where his property was located, Bismarck launched the slogan of the ethnic war between the Germans and the Slavs. He made the border a protective curtain of the German ethnic self - what we have called the "biological self," referring to the Macedonian health border. Ethnic war is border war (Grenzkrieg), said Bismarck. Of all these, the health border is only a special case, as we see in Macedonia. The territorialization of the empire invented by the Romans (Luttwak, 1976) was thus followed by the territorialization of imperialism. A step further, and the totalitarian twentieth century invented the territorialization of terror, the mission of border zones being to ensure a state's control over its borders, to clean its margins by removing undesirable populations or even by "de-civilizing" said populations dying of hunger, typhus, and other diseases resulting from inhuman living conditions and famine. Border areas, whether sanitary or not, have been the subject of sustained attention by historians of genocide and ethnic cleansing in recent years. Naimark (2010) and Snyder (2010), for instance, have amply demonstrated that genocide and ethnic cleansing may be seen as a story of border areas. For the security of the totalitarian State, there is a paradoxical centrality of margins and border areas, a paradoxical centrality that is also shared, of course, by border health zones.

The border policy specific to totalitarianism certainly goes beyond the scope of this article, but it should be noted that the border health zone put forward by the International Health Conference in Warsaw in 1922 took shape precisely in a context of contestation of the territorial limits of states (when the new national states of central and eastern Europe were created), the collapse of empires (Austro-Hungarian, Russian), and even the collapse of sovereignty (in the border zone). Exactly the "fatal formula" which, according to Niall Ferguson (2006, p.646), would pave the way for genocides and (civil) wars in the twentieth century.

To conclude, a final word about the problem of the borderless sanitary zone, and more generally of borderlessness. Historically, borderlessness refers to functionalism, a specific ideology of the international public health community and multilateral organizations. We have already touched on this theme by referring to the third stage of our typology of the health border: debordering. Functionalism became fashionable in multilateral organizations around 1930-1940 (Mitrany, 1946). An ideology and a practice of international relations, functionalism wanted to substitute "foreign affairs" with "world affairs." International relations should be governed by a "world council for world affairs" (Madariaga, 1937, p.105). This doctrine sought to help solve a problem people worried very much about. In the aftermath of the First World War, contemplating the widespread disorder and health threats pounding eastern European and Russian-Ukrainian populations, the head of the International Health Board of the Rockefeller Foundation recommended combining health and peacemaking in the fight to stabilize Europe. Because infections were widespread, 
only a counter-offensive on a grand scale, freed from the corset of national state borders and centrally organized under the authority of an international body, could heal Europe's ailments. Accordingly, politics would cease to take the lead and let technique stand at the helm. The response to the threats needed to "transfer wider and wider areas of public policy from politics to expertise" (Haas, 1992, p.8). Immediately after the war, the president of the Rockefeller Foundation made things clear. Activities like reparations, delimitation of national state boundaries, and so on, which "the League has nothing to do with," should be separated from "these relatively non-controversial matters ... where everybody has everything to gain and nothing to lose," such as public health (Fosdick, 1966, p.20, 22).

The notion of functionalism led to another vital question. The 1919 outbreak in eastern Europe (typhus, cholera, dysentery, TB) showed that debordering could not be limited to superimposing a functional geography on the political geography of failed states. A new paradigm of the health border was being established. In the paper submitted, we say that the "sanitary zone" tried to channel the flow of refugees, not within the traditional state-people-territory framework, but by temporarily and locally suspending national laws for the sake of a more functional approach. According to Diener and Hagen (2012), a world of flows (capital, goods, human beings) is starting to erase the world of bounded places. More than that, nowadays borders are becoming more open to certain categories of people while more closed to others; a world of flows is silently instituting what we have called "contingent sovereignty," while the State institutionalizes graduated citizenship. These changes in addition to the proliferation of neoliberal economic spaces suggest "the emergence of 'neofeudal' sociopolitical networks in which certain classes and institutions garner broad privileges, while others face greater discrimination and regulation" (Diener, Hagen, 2012, p.122-123).

In any case, this is what the paper attempts to identify. Perpetual de-territorialization leading to a borderless world is highly unlikely, even when it comes to international public health. Much of the possible suspension of bordering would eventually conduct to a process of rebordering. And while very sketchy, our example of Sierra Leone's experimentation of a "neofeudal" boundary during the 2014 Ebola epidemic still shows this process of deand re-bordering in a time of sanitary alert. Arguably, the borderless sanitary frontier is something of a delusion, although a delusion of a critical sort, casting light upon the whole process of sanitary borders across the twentieth and twenty-first centuries.

\section{NOTES}

${ }^{1}$ For a recent contribution to the chapter on human rights in relation to the sanitary frontier that we do not deal with here, see Taylor (2013). I would like to thank Prof. Eve Seguin (UQAM) for bringing this article to my attention.

${ }^{2}$ For a bibliography of the Austrian military frontier, see: Wessely (1971, 1974, 1976); Thomas (1984).

${ }^{3}$ The first study about the Militärgrenze, mentioned earlier, was published in 1957 and written by Erna Lesky, professor of the history of medicine in Vienna in 1962 and director of the Institute of the History of Medicine, University of Vienna, from 1960 to 1979 (Koelbing, 1987, p.43). While she worked on Pestcordon, Erna Lesky was an associate of the Institute of Hygiene at the University of Vienna, of which Richard Bieling, a former employee of the IG-Farben virology laboratory and top dog in Nazi vaccinology, had been director since 1952 (Hubenstorf, 1996, p.12). About Bieling, see Weindling (2000). On 25 Septembre 
1941, in a Libre propos, Hitler uses the expression "lving wall" when referring to the "fontier" that separates the Germanic world from the Slav world and to "Lebensraum" (Duroselle, 1990, p.229-242). The Führer had, however, been overtaken by a so-called Intellectuals' Address, Summer 1915, calling for an increased German colonization in former Russian (Polish) territory and for the building of a "human frontier wall" (quoted in Mazower, 2008, p.2).

${ }^{4}$ For more on this, see Zylberman, Flahault (2017).

${ }^{5}$ For a treatment of the 2009-2010 flu pandemic through the lense f security, see Flahault, Zylberman (2010).

${ }^{6}$ More on Jovan Cvijic (1865-1927), who sat with the Yugoslavian delegation at the Peace Conference, in Wilkinson (1951, p.202-203, 215, 225).

${ }^{7}$ Ancel was alluding to Haushofer (1927).

8 "We call reticular borders, those boundaries which tightly interlock with technical networks and which match them ... There are no longer linar, multi-purpose border but rather control points which develop wihtin ever-specialised spaces and align themselves accordingly ... It is as if these state borders were shedding their state 'exclusitivity' as they become more technical and networked" (Groupe Frontière, 24 Oct. 2004).

\section{REFERENCES}

ALBERT, Mathias; BROCK, L.

Debordering the World of States: new spaces in international relations. New Political Science, v.18, n.1, p.69-106. 1996.

ANCEL, Jacques.

Géographie des frontières. Paris: Gallimard. 1938.

ANCEL, Jacques.

La Macédoine: son évolution contemporaine. Paris: Delagrave. 1930.

BALDWIN, Peter.

Contagion and the State in Europe, 1830-1930.

Cambridge: Cambridge University Press. 1999.

BRAUDEL, Fernand.

La Méditerranée et le monde méditerranéen à l'époque de Philippe II. v.2. Paris: Armand Colin. 1966.

BZREZINSKI, Zbigniew.

Strategic vision: America and the crisis of global power. New York: Basic Books. 2012.

CIPOLLA, Carlo M.

Fighting the plague in seventeenth-century Italy. Madison, WI: The University of Wisconsin Press. 1981.

COKER, Richard J.; INGRAM, Alan.

Passports and pestilence: migration, security and contemporary border control of infectious diseases. In: Bashford, A. (Ed.). Medicine at the border: disease, globalization and security, 1850 to the present. Basingstoke: Palgrave Macmillan. p.159-176. 2006.

COLLIN DAVIES, Cuthbert.

The problem of the north-west frontier, 1890-1908. London: Barnes \& Noble. [1932] 1975.

CUETO, Marcos; BROWN, Theodore M.; FEE, Elizabeth.

The World Health Organization: a history.

Cambridge: Cambridge University Press. 2019.
CVIJIC, Jovan.

La péninsule balkanique: géographie humaine. Paris: Armand Colin. 1918.

DIENER, Alexander C.; HAGEN, Joshua.

Borders: a very short introduction. New York:

Oxford University Press. 2012.

DUROSELLE, Jean-Baptiste.

Les frontières: vision historique. Relations

Internationales, n.63 (automne), numéro spécial, p.229-242. 1990.

FAUVEL, Antoine.

Sur les quarantaines à Suez [Extrait de 17 avril 1882]. Comptes rendus hebdomadaires des séances de l'Académie des sciences. t.94. 1882.

FERGUSON, Niall.

The war of the world: twentieth-century conflict and the descent of the West. New York: Penguin. 2006.

FIDLER, David P.

From International Sanitary Conventions to global health security: the new international health regulations. Chinese Journal of International Law, v.4, n.2, p.1-68. 2005.

FIDLER, David P.

SARS, governance and the globalization of disease. Basingstoke: Palgrave. 2004.

FLAHAULT, Antoine; ZYLBERMAN, Patrick. Influenza pandemics: past, present and future challenges. Public Health Reviews, v.32, n.1, p.319-340. 2010.

FOSDICK, Raymond B.

Raymond Fosdick to Newton Baker. London, August 15, 1919. In: Fosdick, R.B. Letters on the League of Nations: from the files of Raymond B. Fosdick. Princeton: Princeton University Press. p.20-22. 1966. 
FOUCHER, Michel.

L'obsession des frontières. Paris: Perrin. 2012.

FRANKEL, Todd C.

The last Ebola-free district in Sierra Leone is now an Ebola "hotspot". The Washington Post. Available at: <https://www.washingtonpost. com/news/storyline/wp/2014/11/12/the-lastebola-free-district-in-sierra-leone-is-now-anebola-hotspot/>. Access on: 3 July 2020. 12 Nov. 2014.

FRANKEL, Todd C.

The fight to save the last Ebola-free district in Sierra Leone. The Washington Post. Available at: <https://www.washingtonpost.com/news/ storyline/wp/2014/10/10/the-fight-to-save-thelast-ebola-free-district-in-sierra-leone/>. Access on: 3 July 2020. 10 Oct. 2014.

FRIED, Linda P. et al.

Global Health is public health. The Lancet, v.375, p.535-537. 2010.

FUKUYAMA, Francis.

State Building: governance and world order in the twenty-first century. London: Profile Books. 2004.

GEOUFFRE DE LA PRADELLE, Paul. La frontière. Paris: Les Editions Internationales. 1928.

GOODMAN, Neville M.

International health organizations and their work. Edinburgh: Churchill Livingstone. 1971.

GOSTIN, Lawrence O.

International Infectious Disease Law:

Revisions of the World Health Organization's International Health Regulations. JAMA, v.291, n.21, p.2623-2627. 2004.

GROUPE FRONTIÈRE.

La frontière, un objet spatial en mutation. EspacesTemps.net (online). Available at: <http:// www.espacestemps.net/articles/la-frontiere-unobjet-spatial-en-mutation/>. Access on: 3 July 2020. 24 Oct. 2004.

\section{HAAS, Peter M.}

Introduction: epistemic communities and international policy coordination. International Organization, v.46, n.1, p.1-35. [Special issue Knowledge, Power and International Policy Coordination, edited by Haas, P.M.]. 1992.

HAUSHOFER, Karl.

Grenzen, in ihrer geographischen und politischen Bedeutung. Berlin: Wowinckel. 1927.

HOLLMANN, A. H.

Kolonisation und Entwicklung der

Landwirtschaft in Südserbien (Makedonia).

Berichte über Landwirtschaft: Zeitschrift f.
Agrarpolitik $u$. Landwirtschaft, Neue Folge, 8, p.293. 1928.

HUBENSTORF, Michael.

Von Erfolg und Tragik einer

Medizinhistorikerin: Erna Lesky (1911-1986).

In: Meinel, Cristoph; Renneberg, Monika

(Hrsg.). Geschlechterverhältnisse in Medizin,

Naturwissenschaft und Technik. Stuttgart: Verlag

für Geschichte der Naturwissenschaften und der Technik. p.98-109. 1996.

KISSINGER, Henry.

World order. New York: Penguin Press. 2014.

KITRON, Uriel.

Malaria, agriculture, and development: lessons from past campaigns. International Journal of Health Services, v.17, n.2, p.296-326. 1987.

KOELBING, Huldrych M.

In memoriam: Erna Lesky (1911-1986). Gesnerus, v.44, n.1-2, p.3-5. 1987.

KOPLAN, Jeffrey P. et al.

Toward a common definition of global health. The Lancet, v.373, p.1993-1995. 2009.

LATTIMORE, Owen.

Origins of the Great Wall of China: a frontier concept in theory and practice. In: Lattimore, Owen. Studies in frontier history: collected papers 1928-1958. London: Oxford University Press. $1962 \mathrm{a}$.

LATTIMORE, Owen.

Studies in frontier history. Paris: Mouton. 1962b.

LEE, Kelley; BUSE, Kent; FUSTUKIAN, Suzanne. Health policy in a globalising world. Cambridge: Cambridge University Press. 2002.

LESKY, Erna.

Die österreichische Pestfront an der k. k.

Militärgrenze. Saeculum, v.8, p.82-106. 1957.

LUTTWAK, Edward N.

The grand strategy of the Roman Empire.

Baltimore: The Johns Hopkins University Press. 1976.

MADARIAGA, Salvador de.

Theory and practice in international relations. Philadelphia: Swarthmore College. 1937.

MAE.

Ministère des Affaires Étrangères.

Correspondance commerciale et consulaire, Djeddah, Dubreuil. 27 Mar. 1867.

MAE.

Ministère des Affaires Étrangères.

Correspondance commerciale et consulaire, the Commercial Department to the French viceconsul in Djeddah (Dubreuil). 3 Aug. 1867. 
MAIER, Charles S.

Among empires: American ascendancy and its predecessors. Cambridge, MA: Harvard University Press. 2006.

MARRUS, Michael R.

The unwanted: European refugees in the twentieth century. New York: Oxford University Press. 1985.

MAZOWER, Mark.

Hitler's empire: Nazi rule in occupied Europe. London: Allen Lane. 2008.

MAZOWER, Mark.

Dark continent: Europe's twentieth century. London: Penguin Books. 1998.

MERTON, Robert K.

Science and technology in a democratic order. Journal of Legal and Political Sociology, v.1, p.115126. 1942.

MEYER, H.

Public health in French Indo-China. Washington D.C. 1944. 8A/43045/21641 (Archives of The League of Nations, Geneva). 1944.

MITRANY, David.

A working peace system: an argument for the functional development of international organization. London: National Peace Council. [1943] 1946.

MOULIN, Anne-Marie.

Le dernier langage de la médecine: histoire de l'immunologie de Pasteur au sida. Paris: Presses Universitaires de France. 1991.

NAIMARK, Norman N.

Stalin's genocides. Princeton: Princeton University Press. 2010.

NOUZILLE, Jean.

Histoire de frontières: l'Autriche et l'Empire ottoman. Paris: Berg international. 1991.

OTTOLENGHI, Donato.

Rapport sur le voyage de la commission du paludisme en Yougoslavie. C.H./Malaria/19 (Archives of the League of Nations, Geneva). 1924.

PANZAC, Daniel.

Quarantaines et lazarets: l'Europe et la peste d'Orient, XVIIe-XXe siècles. Aix-en-Provence: Edisud. 1986.

\section{PROTOCOLES...}

Protocoles et procès-verbaux de la Conférence sanitaire internationale de Rome inaugurée le 20 mai 1885, p.56: Annex v to Protocol n. 1, record from the conclusions adopted by the Conference of Vienna, 1874 (land quarantines); and p.348: record of the conclusions adopted by the technical committee of the Conference of Rome (river cordons sanitaires). Rome: Imprimerie du Ministère des Affaires étrangères. 1885.

PROUST, Adrien.

La défense de l'Europe contre la peste et la Conférence de Venise de 1897. Paris: Masson. 1897.

PROUST, Adrien.

L'orientation nouvelle de la politique sanitaire. Paris: Masson. 1896.

RAJCHMAN, Ludwik.

Ludwik Rajchman to W. Rose, Feb. 18, 1922.

RAC/1.1./100 International/ 20/165 (Rockefeller Archive Center, New York). 1922a.

RAJCHMAN, Ludwik

Ludwik Rajchman to L. Bernard, Feb. 27, 1922. R820/12B/26208/11346 (Archives of the League of Nations, Geneva). 1922b.

REID, Stuart.

Global health gets a checkup: a conversation with Tedros Adhanom Ghebreyesus. Foreign Affairs. Available at: <https://www.foreignaffairs. com/interviews/2017-08-15/global-health-getscheckup.>. Access on: 3 July 2020. 2017.

REY, Henry.

Les quarantaines. Archives de médecine navale, v.22, p.124-136, 184-200, 310-313. 1874.

ROFF, William R.

Sanitation and security: the imperial powers and the nineteenth century Hajj. In: Serjeant, R. B.; Bidwell R. L. (Ed.). Arabian Studies. v.6. p.143160. London: Scorpion Communication. 1982.

ROSE, Wickliffe.

Conditions in Eastern European Countries, 14/3/1920. RAC, 1.1/700 Europe/16/121

(Rockefeller Archive Center, New York). 1920.

ROTHENBERG, Gunther E.

The Habsburg military border system: some reconsiderations. In: Kiràly, Béla K.; Rothenberg, Gunther, E. (Ed.). War and society in east central Europe. v.1. New York: Brooklyn College Press. 1979.

ROTHENBERG, Gunther E.

The Austrian sanitary cordon and the control of bubonic plague: 1710-1871. Journal of the History of Medicine and Allied Sciences, v.28, n.1, p.15-23. 1973.

ROTHSTEIN, Mark A. et al.

Quarantine and isolation: lessons learned from SARS. A report to the Centers for Disease Control and Prevention. Louisville: Institute for Bioethics, Health Policy and Law/University of Louisville School of Medicine. 2003. 
SNYDER, Timothy.

Bloodlands: Europe between Hitler and Stalin. New York: Basic Books. 2010.

\section{SOCIETÉ DES NATIONS.}

Conférence sanitaire européenne réunie à Varsovie du 20 au 28 mars 1922. Genève: Ministère des Affaires étrangères, MAE/Europe 1918-40/Pologne 272/221. 3 Apr. 1922.

STAMPAR, Andrija.

On health politics (1919). In: Stampar, Andrija; Grmek M.D. (Ed.). Serving the cause of public health: selected papers of Andrija Stampar. Zagreb: Andrija Stampar School of Public Health. 1966.

TAYLOR, Alan J.P.

The Habsburg Monarchy 1809-1918. London: Penguin Books. [1948] 1990.

TAYLOR, Rosemary C.R.

The politics of securing borders and the identities of disease. Sociology of Health \& Illness, v.35, n.2, p.241-254. 2013.

THOMAS, Colin.

The anatomy of a colonization frontier: the Banat of Temesvar. Austrian History Yearbook, v.19, n.2, p.3-22. 1984.

TOMASEVICH, Jozo.

Peasants, politics, and economic change in Yugoslavia. Stanford: Stanford University Press. 1955.

UNVER, Süheyl. A.

Les épidémies de choléra dans les terres balkaniques aux XVIIIe et XIXe siècles. Études balkaniques (Sofia), v.4, p.89-97. 1973.
VIDAL DE LA BLACHE, Paul.

La France de l'est (Lorraine-Alsace) 1917. Paris: La Découverte. 1994.

WEINDLING, Paul J.

Epidemics and genocide in Eastern Europe 1890 1945. Oxford: Oxford University Press. 2000.

WESSELY, Kurt.

Zur Bibliographie der Militärgrenze.

Österreichische Osthefte, v.18, p.90-94. 1976.

WESSELY, Kurt.

Zur Bibliographie der Militärgrenze.

Österreichische Osthefte, v.16, p.280-328. 1974.

WESSELY, Kurt.

Zur Bibliographie der Militärgrenze.

Österreichische Osthefte, v.13, p.248-259. 1971.

WILKINSON, Henry R.

Maps and politics, a review of the ethnographic cartography of Macedonia. Liverpool: Liverpool University Press. 1951.

ZINSSER, Hans.

Rats, lice and history. London: Penguin Books. [1935] 2000.

ZYLBERMAN, Patrick; FLAHAULT Antoine. Introduction to history and global health. Gesnerus, v.74, n.2, p.159-172. 2017. 